International Journal of English Literature and Social Sciences
Vol-7, Issue-1; Jan-Feb, 2022
Journal Home Page Available: https://ijels.com/
Journal DOI: $10.22161 /$ ijels

Peer-Reviewed Journal

\title{
Hayavadana and the Contemporary Theatre
}

\author{
Dr. Jayalakshmi B ${ }^{1}$, Dr. Sowmya $\mathrm{A}^{2}$ \\ ${ }^{1}$ Asst Prof of English, Govt Home Science College for Women, Holenarasipura, Hassan. \\ ${ }^{2}$ Asst Prof of English, Govt First Grade College, Krishnaraja Sagara, Mandya.
}

Received: 26 Nov 2021; Received in revised form: 15 Jan 2022; Accepted: 22 Jan 2022; Available online: 29 Jan 2022

(C)2022 The Author(s). Published by Infogain Publication. This is an open access article under the CC BY license

(https://creativecommons.org/licenses/by/4.0/).

\begin{abstract}
Hayavadana(1971) by Girish Karnad is an experimental play in many ways as it adopts stylistics features of the two major theatre forms moving away from the regionalist tradition of drama: Epic and Absurd. The Absurd dramatic tradition presents the post-modern human condition as against the conventional depiction of life. The conventional drama presents plays in a structured way with its beginning, middle and end. This paper attempts to trace Hayavadana in the light of both theatre traditions to evaluate how the play itself was a new influence on Indian drama that merged in it the influence of the existential philosophy of the West as reflected in the rapidly evolving theatre forms while presenting a tale from mythology on stage. Hence the paper attempts to unravel the enigmatic human relationship in the light of absurdism and incompleteness as a whole. Therefore, the paper is divided into two parts to understand the influence of the absurd movement on the theatrical style and to bring out the absurdity of the human relationships.Absurd Theatre, a form heralded by its proponents Samuel Beckett, Jean Genette, and Harold Pinter and Epic Theatre propounded by Bertolt Brecht are both distinct theatre traditions developed in the $20^{\text {th }}$ century.
\end{abstract}

Keywords-Girish Karnad, Absurdity, incompleteness, Bertolt Brecht, Hayavadana.

\section{ABSURDITY OF HAYAVADANA:}

Karnad's plays differ from the contemporary traditional Kannada theatres for their innovative approaches towards drama. He borrows his materials from the treasures of mythology, history, and folktales. The source of Hayavadana has its roots in both Somdatta's Kathsarithsagara, Sanskrit collection of stories and Thomas Mann's The Transposed Heads. The plays of Karna combine the contemporariness of content and reflect the sensibilities, concerns of the modern period too.The viewing of the story with the modern philosophy is essential to the understanding that the human identity irrespective of the ages has always been in a fix. Situating a tale from mythologies in a supposedly contemporary situation adds to the absurd element of the play. The interpolation of the classic with contemporary elements is intended to blur the period of the plot. In a drama within the drama, Bhagavatha, the narrator narrates the story of Devadutta-Kapila-Padmini as an occurrence of the past in the city of Dharmapura ruled by Dharmasheela. The reference to rishis, imaginary kingdom of Dharmapura gives us the impression that the drama has taken place many years ago. However, the introduction of Padmini's son at the end of the play confounds the time period. Hayavadana singing a national anthem add the contemporary dimension to the plot. The plot has an intersection of the stories of Padmini-Devadutta- Kapila and Hayavadana. Both stories underscore the identity crisis as the main thread running through the two plots. However, the strong undercurrent messages in both the stories are the misery of human condition, its chaos and sheer despair.

Hayavadana resembles the Theatre of the absurd in certain aspects that subscribe to the tradition. The setting of the play is unrecognizable and it is often difficult to guess the period of the plot. The plot does not have a conventional division of three or five acts arrangements. It has two acts, the story of Padmini and Hayavadana overlapping in both the acts. The play's central focus is human relationship as well as the human nature. Padmini, Kapila, Devadutta's suffering and tragedy are linked to the frictions between social expectations of human relations versus the arbitrary nature of the sexual tensions/preferences. Ghastly scenes of suicide follow 
light, humorous scenes involving Bhagavatha, poetic scenes in which Devadutta professes his love towards Padmini. This mixing of comedy and tragedy, strongly criticized by Aristotle in Poetics, is a stylistic feature of the Avant Garde writers. It even sends out signals of the impression of disunity. However, Hayvadana'saffiliations to the Theatre of the Absurd seem to come from the fact that it presents a sense of despair and meaninglessness of human existence. Completeness is presented as an insufficient as well as an incomplete ideal that evades reason and logic. The plots that are cyclic and ending in the same way they began further characterize the Absurd Theatre. Language is superficial and superfluous because communication-using words are highly impossible. The story takes place in a dream-like setting in which the characters are bewildered by the chaotic turn of events.

It also reflects the Brechtian influence like the introduction of Chorus who acts in the play and involves the audience in a way of conversation to induce the realistic touch and to reduce artistic illusion. Another frequent feature of the Epic theatre is introducing play within a play. Hayavadana has speech that is both poetic and purposeful. It also has the use of songs, connected narratives and the focus is the study of human relations replacing the study of human nature.

Hayavadana as the name itself indicates is a man who has the head of a horse and human body frustrated of achieving the completeness in his life. Both Padmini and Hayavadana share the similar experiences in the play. Padmini who represents the collective female sensibilities of the modern age, aspires for an ideal husband having all the qualities of intelligence, beauty and physical prowess combined in one man, a good mixture of "fabulous body and fabulous brain." Her hunting goes in vain, as it does not exist in the real sense of the word. In the same way, Hayavadana's quest for attaining completeness is utterly a fiasco.

The opening scene is not only striking but quite appropriate from the dramatic technique is concerned. The play opens with the mask of Lord Ganesha who embodies the concept of incompleteness. Therefore, the use of Ganesha and Hayavadana on stage symbolically connects with life of the heroine Padmini. Bhagavatha, the narrator cum commentator, introduces the characters to the audience. His conversation with the Actor illustrates that some of these radical techniques have been highly influenced by the Brechtian Epic theatre. Bhagavatha is the one who speaks with the characters and comments on their thoughts. Bhagavatha is the main sutradara, the main thread of the play who connects and reconnects the characters by his narration and songs. Interestingly, he is like many Brechtian characters, a 'SpectActor' and a detached observer. Bhagavatha is quite aware of the truth that he is on stage and to deliver his job. He wants the audience to 'think' of the particular situation, which he is dealing with. He develops a sort of rational thinking among the audience, which is further emphasized by Hayavadanawhen his civic sense is questioned. The actors, (Actor I and Actor II) have a stage presence in the drama they are supposed to be acting, rather seen on stage while hassling with Hayavadana. This is again an influence of Brechtian theatre where the characters engage in conversation with the actors so to make audience realize that they are watching the play.

Karnad's use of dolls in the play further enhances the dramatic beauty, which plays a vital role in it. The entry of two dolls is really striking who are totally different and human like in their nature. The intervention of dolls scene highlights the extremity of psychological understanding of the characters. The dolls go deep inside the minds of the characters and exhibit their hidden feelings to the audience. If Karnad has not made use of these dolls, the audience would have failed to grasp the unknown feelings of these characters. The dolls expose the true nature of human minds and exemplify the dichotomy between the real personality and the hidden temperament. These dolls are also used to interpret the dreams of Padmini. This is one of the remarkable devices used on stage. These dolls render the hidden thoughts of characters to the audience by depicting their true natures. Kirtinath Kurtkoti rightly remarks about Karnad's theatrical style:

Karnad uses the conventions and motifs of folk tales and folk theatre-masks, curtains, dolls, the -within-a-story-to create a bizarre world. It is a world of incomplete individuals, indifferent gods, dolls that speak and children, who cannot, a world indifferent to the desires and frustrations, joys and sorrows of human beings. .. (Hayavadana, vii).

Throughout the play, stage is occupied with full of songs of female chorus and Bhagavata, the paintings of sati, music and use of dolls as a whole is employed to evoke a sense of dramatic success. The playwright also makes use of classical references; the rishi and the Gandhrava serve the purpose while convincing the audience. These dramatic devices not only represent the vividness on stage but places Karnad in a unique position away from the traditional playwrights. Arguably, it provided an exclusive space for the modern theatre replacing the traditional one.

Karnad's makes use of songs, dance, mimes, and masks to heighten the element of absurdity in the drama. One of the techniques employed in the Brechtian theatre is 
"man can change" in the process of the drama. The characters are not stagnant as they appear in the beginning. In the same way, the characters are shown to be in constant turmoil that shifts their ideologies leading to chaos and tragedy. Padmini's character is subjected to numerous changes from the beginning to the end. Denouncing the age-old feminine theories, she acts according to her wishes and crafts her own ideal husband. Unfortunately, it never stays for long and again goes in search of what she dreamt of and ends up by performing sati. Padmini's yearning for her ideal partner keeps on changing till she fulfills it. Therefore, Hayavadana in the sub-plot and Padmini in the main plot consistently change in the course of action. Hayavadana's yearning for completeness turns the table against the assumptions that the best of the things, the converging point of perfection is a farce, unable to bring happiness and satisfaction to any. Ultimately,it results in becoming a complete horse but again unable to get rid of the human voice. Padmini's quest for completeness is fulfilled in the form of her child who along with Hayavadana stands for the future hope and happiness. The mixing of tragic and comic elements is a common trait of the absurd theatre, which often has a happy conclusion.

Characters in Hayavadana are presented as "mechanical puppets," (Esslin foreword xvii) and characterization and motivation often includes "dreams and nightmares; if a good play relies on witty repartee and pointed dialogue, these often consist of incoherent babblings (Esslin foreword xviii). Camus in The Myth of Sisyphus reflects the split between man and his outside world and the lingering loneliness in these lines, "His [man's] is an irremediable exile, because he is deprived of memories of a lost homeland and as much as he lacks the hope of a promised land to come. This divorce between man and his life, the actor and his setting, truly constitutes the feeling of absurdity" (qtd. in The Theatre of the Absurdpg xix).

\section{ABSURDITY OF THE IDEAL OF HUMAN PERFECTION}

The two plots in the play are centered on theme of chasing the ideal of perfection. The two plots are both complementary and averse to one another. Padmini wants the best of both the men- the person she is betrothed toand the person she desires. Padmini's struggles begin when the sustaining of the desired combo fades and Hayavadana's struggle begins when the superior elements of the man/nature species sustained him.He is born with a body of the horse endowed with human voice. The best of both traits or the lack of it is the cause of resentment and frustration in all the characters which is observed by Martin Esslin in The Theatre of the Absurd, "The theatre of the absurd strives to express its sense of the senselessness of the human condition and the inadequacy of the rational approach by the open abandonment of rational devices and discursive thought"(Esslin $\mathrm{xx}$ ).

The theme of loneliness is presented through characterization of the trio, Devadutta-Padmini-Kapila. An irreparable gap exists between Padmini and Devadutta. Padmini is shown to be always coveting Kapila. Devadutta complains explicitly about the growing attachment between Kapila and Padmini. He senses Padmini's passion for the physical charms of Kapila and complains about her "drooling" about him. Kapila professes his passion in silent loyalty. The sexual tensions between Kapila and Padmini are not hard to be noticed by Devadutta. The love triangle is met with an unexpected, tragic end when the two kill themselves in front of the Goddess Kali. Even the Goddess is bored and indifferent looking at the meaningless sacrifice of the sacrificers. Kapila vouches that he is dying for friendship and Devadutta takes oath that he is giving away his life for a word that he gave many years back when he wished to have Padmini in his life. He says that if he ever gets her he would gave his hands to Rudra and head to Kali. He had not taken the promisevery seriously, until when he was disillusioned by the attraction between his wife and his friend.

The sleeping Goddess discerns the fakeness of the reasons of the sacrifice. She doesnot stop the two from killing themselves. Just like the relationships between them, the reasons they profess for their suicide are absurd. Their suicide is prompted by the realization of the senselessness of their living conditions. The dead end they reach in their individual living conditions triggers them to take extreme steps. Mixing of the heads creates another absurd situation where the identities are mixed and confused. The confusion leads to chaos about who is Devadutta and who is Kapila. Devadutta's body with Kapila's head claims to be husband of Padmini and Devadutta refutes the claim of Kapila saying that head is superior therefore he is the rightful husband of Padmini. Padmini is bewildered and happy tochoose Kapila's body with Devadutta's head. The safe option would ensure her the object of her desire and social sanctioning that would recognize Devadutta as her husband. The dejected Kapila abandons his town and starts living in forest. In a few years, the plot repeats that will again end in the death of the trio.

Therefore, situating Hayavadana in two dramatic traditions helps in adapting the Indian theatre to the growing demands for experimentation with different form, content and genres of theatre as was necessitated by contextualizing a myth of the yesteryears in the contemporaneous situation. Besides, the absurdity and 
human existentialism is aptly enacted by the tangled relationship who unsettle in search of completeness.

\section{REFERENCES}

[1] Esslin, Martin. The Theatre of the Absurd. A Doubleday Anchor Original. 1961.

[2] Karnad, Girish. Hayavadana. Oxford.UP. 1975. 